\title{
Allelopathic Activity of Cymbopogon nardus (Poaceae): A Preliminary Study
}

\author{
Prapaipit Suwitchayanon ${ }^{1}$, Piyatida Pukclai $^{1} \&$ Hisashi Kato-Noguchi ${ }^{1}$ \\ ${ }^{1}$ Department of Applied Bioresource Science, Faculty of Agriculture, Kagawa University, Miki, Kagawa, Japan \\ Correspondence: Prapaipit Suwitchayanon, Department of Applied Bioresource Science, Faculty of Agriculture, \\ Kagawa University, Miki, Kagawa 761-0795, Japan. Tel: 81-90-2828-9108. E-mail: s.prapaipit@gmail.com
}

Received: January 4, 2013 Accepted: February 20, 2013 Online Published: March 3, 2013

doi:10.5539/jps.v2v2p1 URL: http://dx.doi.org/10.5539/jps.v2v2p1

\begin{abstract}
The inhibitory effects of aqueous methanol extract of Cymbopogon nardus (L.) Rendle were determined on seedling growth of eight test plant species: alfalfa (Medicago sativa L.), cress (Lepidum sativum L.), lettuce (Lactuca sativa L.), rapeseed (Brassica napus L.), barnyard grass (Echinochloa crus-galli L.), Italian ryegrass (Lolium moltiflorum Lam.), jungle rice (Echinochloa colonum (L.) P. Beauv.) and timothy (Phleum pratense L.). The bioassay was conducted with four extract concentrations $(0.01,0.03,0.1$ and $0.3 \mathrm{~g}$ dry weight equivalent extract $/ \mathrm{mL}$ ). The extracts inhibited significantly shoot and root growth of four test plants such as cress, lettuce, rapeseed and Italian ryegrass at the concentration $\geq 0.03 \mathrm{~g}$ dry weight equivalent extract $/ \mathrm{mL}$. The inhibitions of shoots and roots increased with increasing extract concentrations. The concentrations required for $50 \%$ growth inhibition of all test plants ranged 0.007-0.090 g dry weight equivalent extract $/ \mathrm{mL}$. Roots of all test plants were more sensitive to the extract than their shoots. Lettuce was most sensitive, follows by cress and timothy. The results suggest that $C$. nardus may have allelopathic compounds and may be a candidate for isolation and identification of allelopathic compounds to develop an alternative weed management option.
\end{abstract}

Keywords: allelopathic activity, Cymbopogon nardus, medicinal plant, aqueous methanol extract, inhibitory effect, weed control

\section{Introduction}

When weeds overwhelm in crops, there will be economic losses and low quality yields. Nowadays, weed management is characterized by the heavy use of synthetic herbicides. However, the use of synthetic herbicides may cause adverse effects on the environment, human health and the development of herbicide-resistant weed biotypes (Mosier et al., 1990; Owen \& Zelaya, 2005; Hager \& Refsell, 2008; Campbell et al., 2011; Bhadoria, 2011). Therefore, it is necessary to develop alternative means for weed management strategies based on natural products.

Allelopathy refers to the influence of chemicals released from one plant on the growth and development of other plants by leaching, root exudation, volatilization and decomposition of plant material (Rice, 1974). The importance of allelopathy in weed management and crop productivity has been recognized and various methods have been suggested to know the allelopathic activity (Colquhoun, 2006; Li et al., 2010; Bhadoria, 2011).

Citronella (Cymbopogon nardus (L.) Rendle) is a perennial grass which belongs to Poaceae and distributed in tropical and subtropical areas of southeast Asia (Shasany et al., 2000; Nakahara et al., 2003). This species is known for its pharmacological properties such as antimicrobial, antiinflammatory, antioxidant and mosquitocidal (Nurhanani \& Othman, 2010; Silva et al., 2011; Kongkaew et al., 2011; Sritabutra et al., 2011; Istianto \& Emilda, 2011; Simic et al., 2008). Nakahara et al. (2003) reported that the main constituents of $C$. nardus are geraniol, trans-citral, cis-citral, geranyl acetate, cintronellal and citronellol. Citronellal and linalool among these are the most active compounds to inhibit the growth of fungi Aspergillus flavus, Penicillium adametzii and P. griseofulvum. Moreover, Zeng and Luo (1996) have reported that root exudates of C. citratus, Ageratum conyzoides and Bidens pilosa decreased the germination rate, root length and seedling height of radish, rice and cucumber seedlings. However, to date, no information is available on the allelopathic activity of $C$. nardus. Hence, the present study was focused on determining the inhibitory effects from the extract of $C$. 
nardus on seedling growth of monocot and dicotyledonous species for the purpose of alternative weed management.

\section{Method}

\subsection{Plant Materials}

The whole plants of Cymbopogon nardus (L.) Rendle were collected from Chiang Mai province, Thailand in July 2012. Plants were washed several times to get rid of soil particles, dried in oven at $70^{\circ} \mathrm{C}$ and ground into powder. Dry powder was then vacuum sealed in a plastic bag and kept at $4{ }^{\circ} \mathrm{C}$. Dicotyledonous species such as alfalfa (Medicago sativa L.), cress (Lepidum sativum L.), lettuce (Lactuca sativa L.) and rapeseed (Brassica napus L.) were chosen because of their known seedling growth behavior. Monocotyledonous grass species like barnyard grass (Echinochloa crus-galli L.), Italian ryegrass (Lolium moltiflorum Lam.), jungle rice (Echinochloa colonum (L.) P. Beauv.) and timothy (Phleum pratense L.) were chosen because there are common agricultural weeds.

\subsection{Extraction}

Plant powder $(100 \mathrm{~g})$ was extracted with $1 \mathrm{~L}$ of $70 \%(\mathrm{v} / \mathrm{v})$ aqueous methanol for two days. The extract was then filtered through one layer of filter paper (No. 2; Toyo Ltd., Japan), using a vacuum pump. The residue was extracted again with $1 \mathrm{~L}$ of cold methanol for one day and filtrated. The two filtrates were combined and evaporated with a rotary evaporator at $40^{\circ} \mathrm{C}$ until it was completely dry. Crude extract of $100 \mathrm{~g}$ plant material was dissolved in $150 \mathrm{~mL}$ cold methanol.

\subsection{Bioassay}

The bioassay was conducted with four concentrations $(0.01,0.03,0.1$ and $0.3 \mathrm{~g}$ dry weight equivalent extract $/ \mathrm{mL}$ ). For preparing those concentrations, an aliquot of the extract $(9,27,90$ and $270 \mu \mathrm{L}$, respectively) was added to a sheet of filter paper (No. 2) in $28 \mathrm{~mm}$ Petri dish and evaporated the solvent in a draft chamber. Then, the filter paper was moistened with $0.6 \mathrm{~mL}$ of $0.05 \%(\mathrm{v} / \mathrm{v})$ aqueous solution of polyoxyethylenesorbitan monolaurate (Tween 20; Nacalai, Kyoto, Japan), a surfactant which did not cause any toxic effects. Ten seeds of alfalfa, cress, lettuce, rapeseed or 10 germinated seeds of barnyard grass, Italian ryegrass, jungle rice or timothy were arranged on the filter paper in Petri dishes. For germination, barnyard grass, Italian ryegrass and jungle rice were soaked in distilled water in Petri dish $(9 \mathrm{~cm}$ diameter) and allowed to germinate in the darkness at $25^{\circ} \mathrm{C}$ for $72 \mathrm{~h}$ and timothy were germinated in the darkness at $25^{\circ} \mathrm{C}$ for $96 \mathrm{~h}$.

Control seeds were sown on the filter paper moistened with the aqueous solution of Tween 20 without the extract. The shoot and root lengths of those seedlings were measured at $48 \mathrm{~h}$ after incubation in the darkness at $25{ }^{\circ} \mathrm{C}$ and the percentage length of seedlings was then determined by reference to the length of control seedlings.

The bioassay was repeated three times with 10 plants for each determination. The inhibition percentage was calculated using the equation as follow:

$$
\text { Inhibition }(\%)=[1-(\text { treatment } / \text { control })] \times 100
$$

In addition, the concentrations required for $50 \%$ inhibition $\left(\mathrm{I}_{50}\right)$ of the test plant species in the assay were calculated from the regression equation of the concentration response curves.

\subsection{Statistical Analysis}

All experiments were triple replicated and repeat twice. The statistical data processing were analyzed by SPSS version 16.0 using one-way ANOVA. GraphPad Prism 5.04 was used to analyze the concentrations required for $50 \%$ inhibition.

\section{Results}

\subsection{Effect of Aqueous Methanol Extract of Cymbopogon nardus on Shoot Growth}

The inhibitory effects of the extract on shoot growth of eight test plants were shown in Figure 1. The extract concentration of $0.1 \mathrm{~g}$ dry weight equivalent extract $/ \mathrm{mL}$ completely inhibited shoot growth of lettuce seedlings $(100 \%)$. The extracts inhibited shoot growth of timothy, rapeseed, Italian ryegrass, cress, alfalfa, jungle rice and barnyard grass by $98.75,86.84,84.33,80.88,78.28,68.71$ and $59.70 \%$, respectively. At the concentration of $0.3 \mathrm{~g}$ dry weight equivalent extract $/ \mathrm{mL}$, shoot growth of alfalfa, jungle rice, cress and barnyard grass was inhibited by $90.40,87.41,82.35$ and $70.89 \%$, and shoot growth of lettuce, timothy, rapeseed and Italian ryegrass were completely inhibited. 

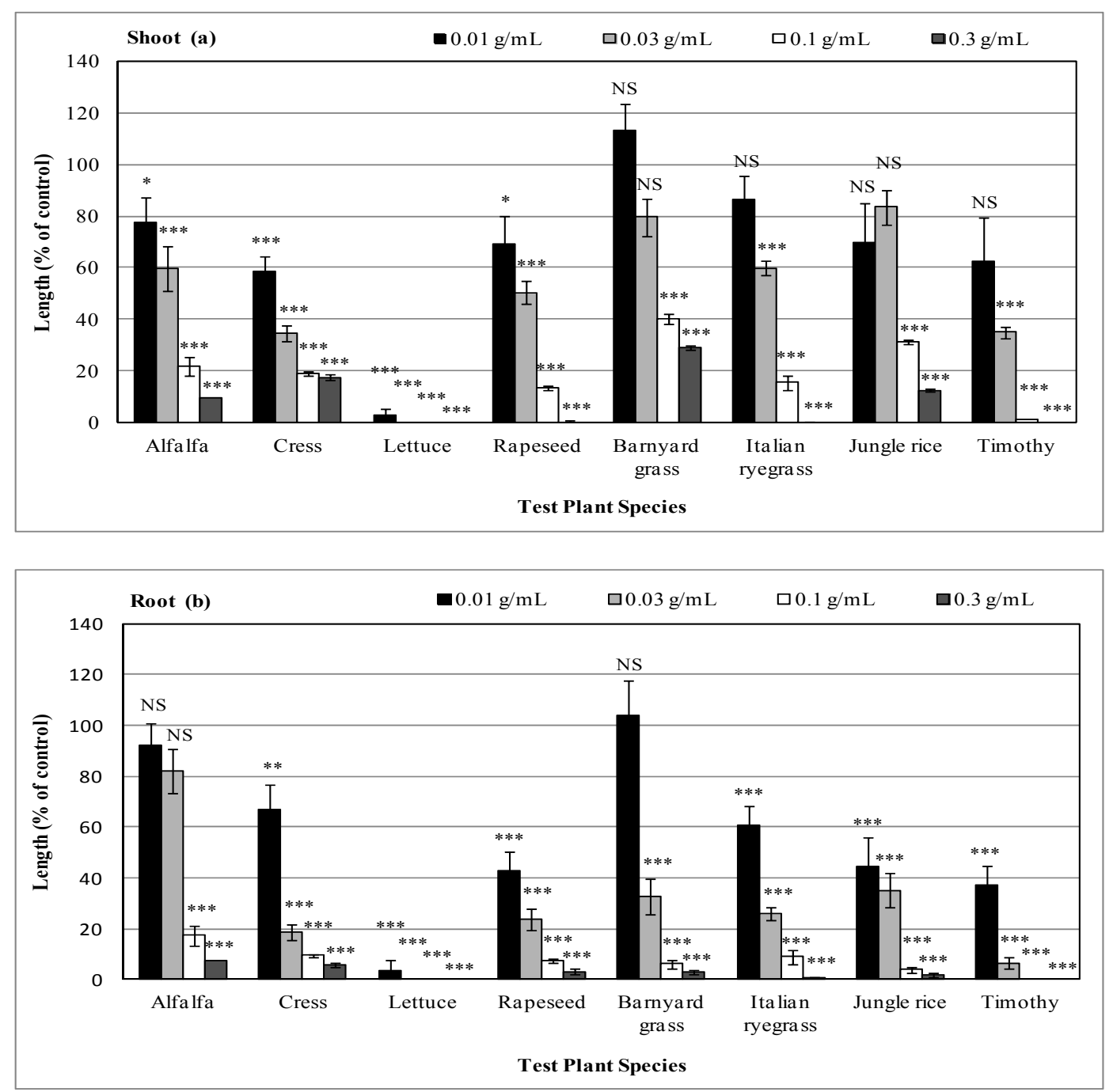

Figure 1. Effects of aqueous methanol extract of Cymbopogon nardus on shoot (a) and root (b) growth of test plant species

The concentrations of the extract corresponded to the extract obtained from $0.01,0.03,0.1$ and $0.3 \mathrm{~g}$ dry weight of $C$. nardus. Means $\pm \mathrm{SE}$ from three independent experiments with 10 seedlings for each determination are shown. ${ }^{*} \mathrm{P}<0.05,{ }^{*} \mathrm{P}<0.01,{ }^{* * *} \mathrm{P}<0.001$ (Student's t-test).

Table 1. The concentrations required for $50 \%$ inhibition $\left(\mathrm{I}_{50}\right)$ on shoot and root growth of the test plant species

\begin{tabular}{ccc}
\hline Test plant species & $\begin{array}{c}\mathrm{I}_{50}(\mathrm{~g} \text { dry weight equivalent extract } / \mathrm{mL}) \\
\text { Shoot }\end{array}$ & Root \\
\hline Alfalfa & 0.037 & 0.054 \\
Cress & 0.014 & 0.014 \\
Lettuce & 0.008 & 0.007 \\
Rapeseed & 0.024 & 0.007 \\
Barnyard grass & 0.090 & 0.024 \\
Italian ryegrass & 0.036 & 0.014 \\
Jungle rice & 0.059 & 0.059 \\
Timothy & 0.015 & 0.007 \\
\hline
\end{tabular}

The values were determined by a logistic regression analysis after bioassays. 
The concentration required for $50 \%$ inhibition was showed in Table 1. Lettuce shoots were the most sensitive to the extracts follow by cress and timothy. Barnyard grass shoots were less sensitive to the extracts.

\subsection{Effect of Aqueous Methanol Extract of Cymbopogon nardus on Root Growth}

At the extract concentration of $0.1 \mathrm{~g}$ dry weight equivalent extract $/ \mathrm{mL}$ completely inhibited root growth of lettuce and timothy seedlings $(100 \%)$, and root growth of jungle rice, barnyard grass, rapeseed, Italian ryegrass, cress and alfalfa was inhibited by $96.15,93.97,92.86,91.04,90.57$ and $82.72 \%$, respectively (Figure 1). At the concentration of $0.3 \mathrm{~g}$ dry weight equivalent extract $/ \mathrm{mL}$, root growth of Italian ryegrass, jungle rice, barnyard grass, rapeseed, cress and alfalfa were inhibited by $99.53,98.25,96.98,96.87,94.26$ and 92.65\%, and root growth of lettuce and timothy were completely inhibited.

The concentration required for $50 \%$ inhibition was showed in Table 1. Lettuce, rapeseed and timothy roots were the most sensitive to the extracts. In contrast, jungle rice roots were less sensitive to the extracts.

\section{Discussion}

Aqueous methanol extract of $C$. nardus had inhibitory effects on both monocotyledonous (barnyard grass, Italian ryegrass, jungle rice and timothy) and dicotyledonous plant species (alfalfa, cress, lettuce, and rapeseed). The extract exhibited significant inhibition of shoot and root growth of cress, lettuce, rapeseed and Italian ryegrass at the concentration $\geq 0.03 \mathrm{~g}$ dry weight equivalent extract $/ \mathrm{mL}(\mathrm{P}<0.001)$ (Figure 1$)$. In addition, eight test plants showed different sensitivity to different extracts and those inhibitions increased with increasing of extract concentrations, suggesting that inhibitory exhibitions were species specific and concentration dependent. The similar results were reported by Ma et al. (2011) that the concentration dependent effects of aqueous extracts from root of Stellera chamaejasme were found on shoot length, root length, number of lateral roots and dry weight of rapeseed, wheat and sesame seedlings. The allelopathic threshold concentration of plant extracts on test plant species have also been reported by Alagesaboopathi and Deivanai (2011); Aliloo et al. (2012); Fateh et al. (2012); Raoof and Siddiqui (2012). Another reason of unequal susceptibility to different concentration was mentioned by Hassan et al. (2012) that this may be due to the differences in seed size and seed coat permeability which influence the uptake of allelopathic compounds.

In addition, the aqueous methanol extract of $C$. nardus showed inhibitory effects on root growth more than their shoot. The related results of root sensitivity to plant extracts have been demonstrated by Olofsdotter et al., (2002); Pukclai et al. (2010); Zhang and Fu (2010); Hussain and Reigosa (2011); Esmaeili et al. (2012). This sensitive might because root is the first organ to contact and absorb the allelopathic compounds (Salam \& Noguchi, 2005). Furthermore, allelopathic compounds may affect root growth by inhibited or retarded germination rate, reduced root radicle or shoot coleoptiles, swelling or necrosis of root tips, discoloration, lack of root hairs, increased number of seminal roots and also reduced dry weight accumulation (Rice, 1974).

The concentrations required for $50 \%$ growth inhibition of test plant species; lettuce was the most sensitive to the aqueous methanol extract, whereas barnyard grass was less sensitive. The studies of numerous researchers have indicated that dicotyledons were more sensitive to allelopathic compounds than monocotyledons (Barnes \& Putnam, 1987; Kruse et al., 2000).

All test plant seeds used in this study were sown in Petri dishes in which only the aqueous methanol extract of C. nardus was added. In addition, those seeds were incubated in the dark condition as describe in Materials and Methods. All seedlings were thus not influenced by light or any nutrient. Thus, inhibition on test plant species might be due to the allelopathic compounds in C. nardus extracts rather than competitive effects for nutrients and light.

In conclusion, the aqueous methanol extract of $C$. nardus exhibited the growth inhibitory effects on eight test plant species, particularly barnyard grass, Italian ryegrass, jungle rice and timothy which are the common weeds in crop fields. The resultant growth inhibitory effects may due to the allelopathic compounds of $C$. nardus. Further studies should be conducted on isolation and identification of allelopathic compounds in the extract of this species. The information obtained could be helpful for environmentally friendly herbicide to control weeds in sustainable way provided the present observation is further corroborated with the study of aqueous extracts of the plant species.

\section{Acknowledgements}

The authors would like to thank the Government of Japan for the supporting scholarship for Prapaipit S.

\section{References}

Alagesaboopathi, C., \& Deivanai, M. (2011). Allelopathic potential of Sesbania grandiflora Pers. on germination 
of Cajanus cajan Millsp. (Redgram) varieties. International Journal of Biosciences, 1(5), 51-55.

Aliloo, A. A., Shahabivand, S., Farjam, L., \& Heravi, S. (2012). Allelopathic effects of pine needle extracts on germination and seedling growth of ryegrass and kentucky bluegrass. Advances in Environmental Biology, 6(9), 2513-2518.

Barnes, J. P., \& Putnam, A. R. (1987). Role of benzoxazinones in allelopathy by rye (Secale cereal L.). Journal of Chemical Ecology, 13(4), 889-906. http://dx.doi.org/10.1007/BF01020168

Bhadoria, P. B. S. (2011). Allelopathy: A natural way towards weed management. American Journal of Experimental Agriculture, 1(1), 7-20.

Campbell, J., Smith, C. M., Hulting, A., \& Thill, D. (2011). Herbicide-Resistant Weeds and Their Management. PNW 437. University of Idaho.

Colquhoun, J. B. (2006). Allelopathy in weeds and crops: myths and facts. Aglime \& Pest Management Conference, 45, 318-320.

Esmaeili, M., Heidarzadel, A., Pirdashti, H., \& Exmaeili, F. (2012). Inhibitory activity of pure allelochemicals on barnyard grass (Echinochloa crus-galli L) seed and seedling parameters. International Journal of Agriculture and Crop Sciences, 4(6), 274-279.

Fateh, E., Sohrabi, S. S., \& Gerami, F. (2012). Evaluation of allelopathic effect of bindweed (Convolvulus arvensis L.) on germination and seedling growth of millet and basil. Advances in Environmental Biology, 6(3), 940-950.

Hager, A. G., \& Refsell, D. (2008). Chapter 13: Herbicide Persistence and How to Test for Residues in Soils. Illinois Agricultural Pest Management Handbook, 279-286. Department of Crop Sciences.

Hassan, M. H., Daffalla, H. M., Yagoub, S. O., Osman, M. G., Gani, M. E. A., \& Babiker, A. E. G. G. (2012). Allelopathic effects of some botanical extracts on germination and seedling growth of Sorghum bicolor L. Journal of Agricultural Technology, 8(4), 1423-1469.

Hussain, M. I., \& Reigosa, M. J. (2011). Allelochemical stress inhibits growth, leaf water relations, PSII photochemistry, non-photochemical fluorescence quenching, and heat energy dissipation in three C3 perennial species. Journal of Experimental Botany, 62(3), 4533-4545. http://dx.doi.org/10.1093/jxb/err161

Istianto, M., \& Emilda, D. (2011). Preliminary study of the activity of some essential oils against Fusarium oxysporum f. sp. cubense. Journal of Fruit and Ornamental Plant Research, 19(2), 111-121.

Li, Z. H., Wang, Q., Ruan, X., Pan, C. D., \& Jiang, D. A. (2010). Phenolics and Plant Allelopathy. Molecules, 15, 8933-8952. http://dx.doi.org/10.3390/molecules 15128933

Kongkaew, C., Sakunrag, I., Chaiyakunapruk, N., \& Tawatsin, A. (2011). Effectiveness of citronella preparations in preventing mosquito bites: systematic review of controlled laboratory experimental studies. Tropical Medicine \& International Health, 16(7), 802-810. http://dx.doi.org/10.1111/j.1365-3156.2011.02781.x

Kruse, M., Strandberg, M., \& Standberg, B. (2000). Ecological effects of allelopathic plants-a review: NERI Technical Reports, No. 315, Silkeborg, Denmark.

Ma, L., Wu, H., Bai, R., Zhou, L., Yuan, X., \& Hou, D. (2011). Phytotoxic effects of Stellera chamaejasme L. root extract. African Journal of Agricultural Research, 6(5), 1170-1176. http://dx.doi.org/10.5897/AJAR10.732

Mosier, D. G., Peterson, D. E., \& Regehr, D. L. (1990). Herbicide mode of action: Cooperative extension service C715, Manhattan, Kansas.

Nakahara, K., Alzoreky, N. S., Yoshihashi, T., Nguyen, H. T. T., \& Trakoontivakorn, G. (2003). Chemical composition and antifungal activity of essential oil from Cymbopogon nardus (Citronella grass). Japan Agricultural Research Quarterly, 37(4), 249-252.

Nurhanani, M. N., \& Othman, A. S. (2010). Antibacterial and antifungal activities of Cymbopogon nardus essential oil. Malay. Journal of Pharmaceutical Sciences, p. 198.

Owen, M. D., \& Zelaya, I. A. (2005). Herbicide-resistant crop and weed resistance to herbicides. Pest Management Science, 61, 301-311. http://dx.doi.org/10.1002/ps.1015

Olofsdotter, M., Jensen, L. B., \& Courtois, B. (2002). Improving crop competitive ability using allelopathy-an example from rice. Plant Breeding, 121, 1-9. http://dx.doi.org/10.1046/j.1439-0523.2002.00662.x 
Pukclai, P., Suenaga, K., \& Noguchi, H. K. (2010). Allelopathic potential and chemical composition of Rhinacanthus nasutus extracts. Allelopathy Journal, 26(2), 207-216.

Rice, E. L. (1974). Allelopathy. New York: Academic Press.

Raoof, K. M. A., \& Siddiqui, M. B. (2012). Evaluation of allelopathic impact of aqueous extract of root and aerial root of Tinospora cordifolia (Willd.) miers on some weed plants. Analele Universităţii din Oradea Fascicula Biologie, 1, 29-34.

Salam, M. A., \& Noguchi, H. K. (2010). Allelopathic potential of methanol extract of Bangladesh rice seedlings. Asian Journal of Crop Science, 2(2), 70-77. http://dx.doi.org/10.3923/ajcs.2010.70.77

Shasany, A. K., Lal, R. K., Patra, N. K., Darokar, M. P., Garg, A., Kumar, S., \& Khanuja, S. P. S. (2000). Phenotypic and RAPD diversity among Cymbopogon winterianus Jowitt accessions in relation to Cymbopogon nardus Rendle. Genetic Resources and Crop Evolution, 47(5), 553-559. http://dx.doi.org/10.1023/A:1008712604390

Silva, C. F., Moural, F. C., Mendes, M. F., \& Pessoal, F. L. P. (2011). Extraction of citronella (Cymbopogon nardus) essential oil using supercritical $\mathrm{CO} 2$ : Experimental data and mathematical modeling. Brazilian Journal of Chemical Engineering, 28(2), 343-350. http://dx.doi.org/10.1590/S0104-66322011000200019

Simic, A., Rancic, A., Sokovic, M. D., Ristic, M., Grujic-Juvanovic, S., Vukojevic, J., \& Marin, P. D. (2008). Essential oil composition of Cymbopogon winterianus and Carum carvi and their antimicrobial activities. Pharmaceutical Biology, 46(6), 437-441. http://dx.doi.org/10.1080/13880200802055917

Sritabutra, D., Soonwera, M., Waltanachanobon, S., \& Poungjai, S. (2011). Evaluation of herbal essential oil as repellents against Aedes aegypti (L.) and Anopheles dirus Peyton \& Harrion. Asian Pacific Journal of Tropical Biomedicine, 124-128. http://dx.doi.org/10.1016/S2221-1691(11)60138-X

Zeng, R., \& Luo, S. (1996). The allelopathic effects of root exudates of Cymbopogon citratus, Ageratum conyzoides and Bidens pilosa. Journal of South China Agricultural University, 17(2), 119-120.

Zhang, C., \& Fu, S. (2010). Allelopathic effects of leaf litter and live roots exudates of Eucalyptus species on crops. Allelopathy Journal, 26(1), 91-100. 